Meta

Journal des traducteurs

Translators' Journal

\title{
A College Curriculum for the Training of Translators and Interpreters in the USA
}

\section{Stefan F. Horn}

Volume 11, numéro 4, décembre 1966

La formation du traducteur

URI : https://id.erudit.org/iderudit/003130ar

DOI : https://doi.org/10.7202/003130ar

Aller au sommaire du numéro

Éditeur(s)

Les Presses de l'Université de Montréal

ISSN

0026-0452 (imprimé)

1492-1421 (numérique)

Découvrir la revue

Citer cet article

Horn, S. F. (1966). A College Curriculum for the Training of Translators and Interpreters in the USA. Meta, 11(4), 147-154. https://doi.org/10.7202/003130ar d'utilisation que vous pouvez consulter en ligne. 


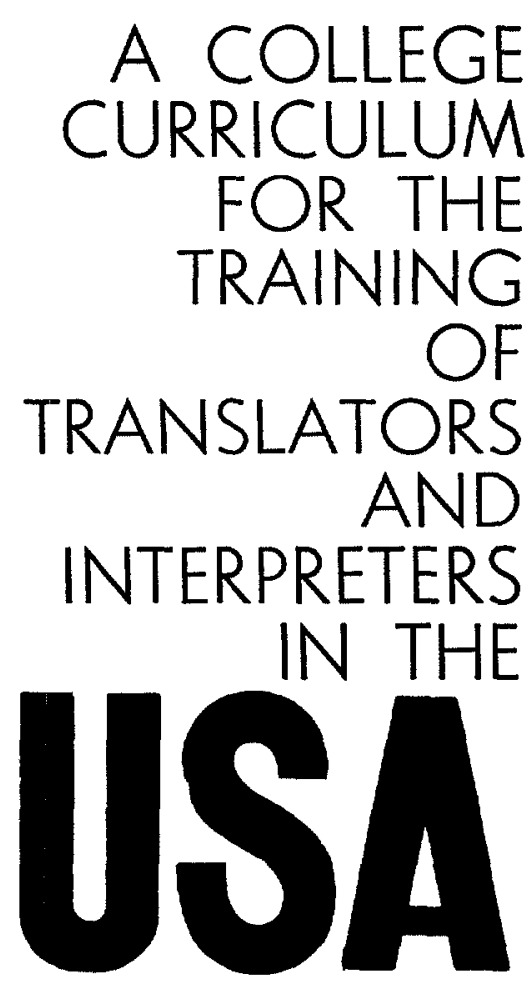

\section{INTRODUCTION}

The following curriculum is based on the assumption that a translator - and an interpreter - should have a thorough training in his active and passive languages as well as a good introduction into various fields of the Social and

Physical Sciences and the Humanities. Upon graduation he should be an expert in his languages but could not claim to be an expert in any particular subject field. But he will be trained to find his own way in any subject field in which he may be called upon to work.

\section{SELECTION OF PROSPECTIVE STUDENTS}

\section{A) HIGH SCHOOL STUDENTS}

Students coming from High School or the equivalent thereof and wishing to take up the Translator Curriculum should have obtained a grade of $" A »$ or $« B »^{1}$ in their native language and at least one foreign language, during their last high school year. While a good high school grade in languages is not in itself a guarantee of success in college language courses, the opposite, i.e. low high school grades in languages, indicates in general a lack of language aptitude. Thus, by choosing 《 good» language students, the possibility of subsequent failures is reduced, if not eliminated. As to non-language subjects, taken during the last year in high

1. I.e.: $80 \%$ or better (Ed.). 
school, the requirement of at least a $《 \mathrm{C} »^{2}$ would reduce the field to those who have already demonstrated a certain capacity for studying.

\section{B) TRANSFER STUDENTS}

Students wishing to transfer from other US colleges or universities, or from foreign universities, or students within the same college (university) wishing to change from a different major to the Translation major should be given credit for all courses they took which they would also have to take in the Translation curriculum, if the grades are high enough. A certain amount of flexibility in computing transfer credits would be in order. However, a minimum of two years, immediately preceding graduation, should constitute the residence requirement.

\section{C) SPECIAL STUDENTS}

Persons interested in the Translator curriculum who have already a college degree or who have had practical experience as translators but wish to improve their knowledge and skill, could be accepted under rules similar to those applied to transfer students and would be known as \& Special Students for the Certificate in Translation ». They would have to take those courses which they had not taken - with the required grades - at another institution of higher learning within the last five years, or for which they cannot prove practical training by taking a test. The minimum residence requirement for Special Students should be one year. They would take the same final examinations as regular degree students. However, they would not receive an academic degree, but the " Certificate of Proficiency in Translation ».

\section{D) LANGUAGE TESTS}

When a student applies for admission to the regular four-year degree curriculum for Translators, his knowledge of at least one foreign language (acceptable for the Translator training) should make it possible for him to fit into the third-year language course (which follows after intensive first-year and second-year courses). $\mathrm{He}$ should pass a test corresponding to this level. Also in his best (native) language he should take a test, including a composition. If he obtains an « $A$ » or « $B »$ on these language tests - fulfilling all the other requirements, of course - he should be admitted to the first year of the B.A. curriculum for Translators. However, if he obtains a lower grade in one or more of his languages, he would have to take as many «preliminary semesters » as necessary, concentrating on his language(s), until he passes the test(s) with the required grade.

\section{CURRICULUM}

\section{A) LANGUAGES}

In order to earn his living, a translator should be able to translate from at least two languages into his best language, called his A language, usually but not

2. I.e.: $70 \%-79 \%$ (Ed.). 
necessarily, his native language. His earning power increases if he can also translate into a foreign language, then called his B language. During his years in college, he should perfect his style and general terminology in his own (A) language, and bring his second-best (B) language to a point where he can translate into it. He should also study another foreign language, preferably of the same family as his A and/or B languages, to a point where he can translate from this language, called his $\mathrm{C}$ language, into his $\mathrm{A}$ language. Complementing the study of languages should be courses in: Modern and Classical Literature, General Linguistics, Lexicology, Machine Translation, and Memory Training.

\section{B) SUBJECT MATTERS}

In order to give the future translator a good basis in various fields of the Social and Physical Sciences and the Humanities on which he can build later on his own, at least the following subjects should be included in the curriculum: Government (Political Science), History, Philosophy, Economics, International Law and International Relations, Art, Physical Sciences, Technology (engineering). Great stress should be laid on informing the student how to proceed on his own if his later professional work calls for highly specialized knowledge (and terminology) in any of these or related fields. These courses are given in English.

\section{C) AREA STUDIES}

The principal countries in which the student's languages are spoken should be the object of comprehensive courses, called Area Studies. These courses should comprise: the history, culture, social and political institutions, and the human and economic geography of these countries. These courses are given in the language of the countries discussed.

\section{D) TRANSLATION COURSES}

Once the student has attained a sufficient degree of mastery in his B language (his best foreign language), translation courses can be introduced, starting in the third semester with translation of general and historical texts, covering in the following semesters those subject matters in which he has already taken the basic course (see curriculum and tables below).

\section{E) REQUIRED GRADES}

Only those subject matter courses and area study courses should be considered as satisfactorily taken in which the student obtained a grade of $\langle\mathrm{C} \gg$ or better, and only those language and translation courses in which he obtained a grade of « $\mathrm{A} »$ or $« \mathrm{~B} »$. The strict enforcement of this rule would require students either to repeat those courses in which they did not obtain the required minimum grade, or give up the major in Translation and switch to another major. 


\section{PROPOSED GURRIĆULUM}

\section{A) TRANSLATOR TRAINING}

Assuming that a student can attend class regularly for 18-19 hours a week, the following curriculum for translator training is proposed:

\begin{tabular}{|c|c|c|}
\hline \multicolumn{3}{|c|}{ FIRST YEAR } \\
\hline $\begin{array}{l}\text { A lang. } \\
\text { A lang. } \\
\text { B lang. } \\
\text { C lang. } \\
\text { Govmt } \\
\text { History } \\
\text { Philosophy }\end{array}$ & $\begin{array}{l}\quad \text { FIRST SEMESTER } \\
\text { Modern Literature I } \\
\text { Advanced Composition I } \\
\text { Style and Composition I } \\
\text { Intensive Basic I } \\
\text { Systems of Governments in selected countries (in English) } \\
\text { World History I (in English) } \\
\text { Logic (in English) }\end{array}$ & $\begin{array}{l}\text { credit hours } \\
2 \\
2 \\
3 \\
5 \\
2 \\
2 \\
\frac{2}{18}\end{array}$ \\
\hline $\begin{array}{l}\text { A lang. } \\
\text { A lang. } \\
\text { B lang. } \\
\text { C lang. } \\
\text { Govmt } \\
\text { History } \\
\text { Philosophy }\end{array}$ & $\begin{array}{l}\text { SECOND SEMESTER } \\
\text { Modern Literature II } \\
\text { Advanced Composition II } \\
\text { Style and Composition II } \\
\text { Intensive Basic II } \\
\text { International Organizations (in English) } \\
\text { World History II (in English) } \\
\text { History of Philosophy (in English) }\end{array}$ & $\begin{array}{l}2 \\
2 \\
3 \\
5 \\
2 \\
2 \\
\frac{2}{18}\end{array}$ \\
\hline \multicolumn{3}{|c|}{ SECOND YEAR } \\
\hline $\begin{array}{l}\text { A lang. } \\
\text { A lang. } \\
\text { A lang. } \\
\text { B lang. } \\
\text { B lang. } \\
\text { C lang. } \\
\text { Economics } \\
\text { Law }\end{array}$ & $\begin{array}{l}\text { THIRD SEMESTER } \\
\text { Classical Literature I } \\
\text { Translation from B lang. into A lang. of general and } \\
\text { Area Studies I historical texts } \\
\text { Modern Literature I } \\
\text { Advanced Composition I } \\
\text { Intensive Advanced I } \\
\text { Principles of Economics I (in English) } \\
\text { Principles of International Law (in English) } \\
\text { FOURTH SEMESTER } \\
\text { Classical Literature II } \\
\text { Translation from B lang. into A lang. of political, } \\
\text { Area Studies II educational, sociological texts } \\
\text { Modern Literature II } \\
\text { Advanced Composition II } \\
\text { Intensive Advanced II } \\
\text { Principles of Economics II (in English) } \\
\text { International Relations }\end{array}$ & $\begin{array}{c}\text { credit hours } \\
2 \\
2 \\
2 \\
2 \\
2 \\
4 \\
2 \\
\frac{2}{18} \\
\\
2\end{array}$ \\
\hline \multicolumn{3}{|c|}{ THIRD YEAR } \\
\hline $\begin{array}{l}\text { A lang. } \\
\text { A lang. } \\
\text { B lang. } \\
\text { B lang. } \\
\text { B lang. } \\
\text { C lang. }\end{array}$ & $\begin{array}{l}\text { FIFTH SEMESTER } \\
\text { Translation from B into A of Conference texts * I } \\
\text { Translation from B into A of economic texts I } \\
\text { Classical Literature I } \\
\text { Translation from A into B of general and } \\
\text { Area Studies I } \\
\text { Style and Composition I }\end{array}$ & $\begin{array}{c}\text { credit hours } \\
2 \\
2 \\
2 \\
2 \\
2\end{array}$ \\
\hline
\end{tabular}




\begin{tabular}{|c|c|c|}
\hline $\begin{array}{l}\text { A lang. } \\
\text { A lang. } \\
\text { B lang. } \\
\text { B lang. } \\
\text { B lang. } \\
\text { C lang. } \\
\text { Art } \\
\text { Linguistics } \\
\text { Phys. Sciences } \\
\text { Technology }\end{array}$ & $\begin{array}{l}\text { History of Art I (in English) } \\
\text { Language and Culture I (in English) } \\
\text { Introduction to Phys. Sciences I (in English) } \\
\text { Introduction to Technology I (in English) } \\
\text { SIXTH SEMESTER } \\
\text { Translation from B into A of Conference texts * II } \\
\text { Translation from B into A of economic texts II } \\
\text { Classical Literature II } \\
\text { Translation from A into B of political, educational, } \\
\text { Area Studies II } \\
\text { Style and Composition II } \\
\text { History of Art II (in English) } \\
\text { Language and Culture II (in English) } \\
\text { Introduction to Phys. Sciences II (in English) } \\
\text { Introduction to Technology II (in English) }\end{array}$ & $\begin{array}{r}1 \\
1 \\
2 \\
2 \\
\mathbf{1 9} \\
2 \\
2 \\
2 \\
2 \\
2 \\
2 \\
3 \\
1 \\
1 \\
2 \\
2 \\
\mathbf{1 9}\end{array}$ \\
\hline & FOURTH YEAR & \\
\hline $\begin{array}{l}\text { A lang. } \\
\text { A lang. } \\
\text { A lang. } \\
\text { A lang. } \\
\text { A lang. } \\
\text { A lang. } \\
\text { A and B lang. } \\
\text { B lang. } \\
\text { B lang. } \\
\text { C lang. } \\
\text { Linguistics } \\
\text { Linguistics }\end{array}$ & 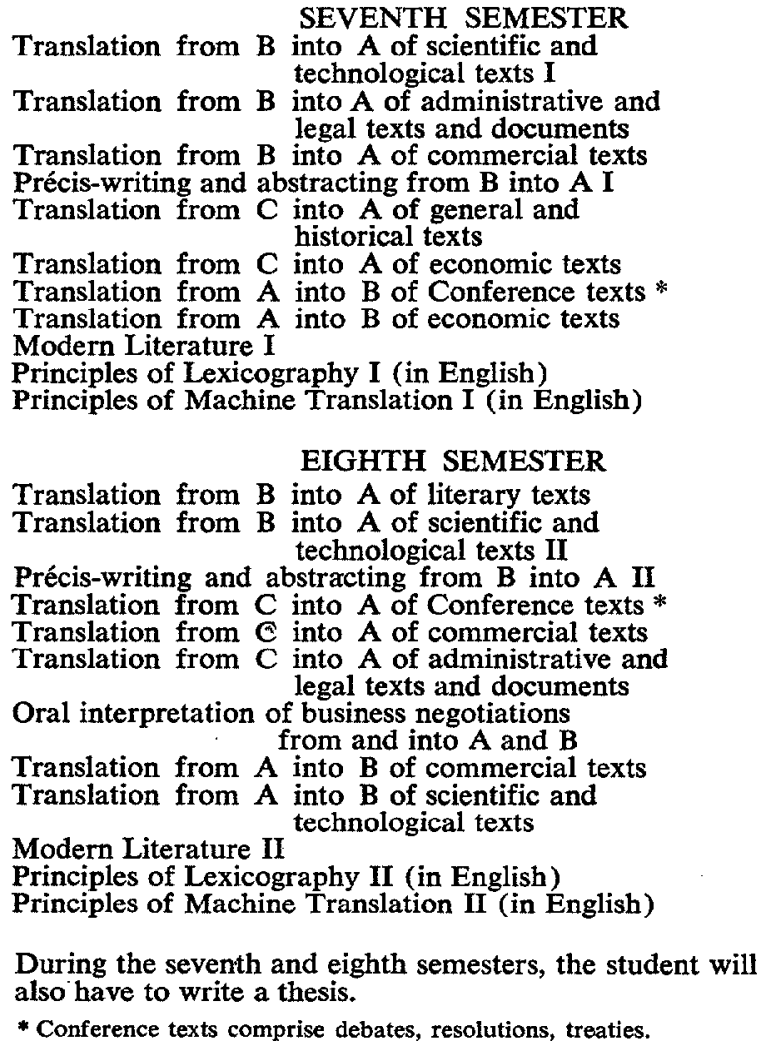 & $\begin{array}{c}\text { credit hours } \\
2 \\
2 \\
1 \\
1 \\
2 \\
2 \\
2 \\
2 \\
2 \\
1 \\
\frac{1}{18}\end{array}$ \\
\hline
\end{tabular}

\section{Examinations}

While the courses given during the seventh and eighth semesters should - like all the courses in the lower semesters - end with the usual semestrial examinations, there should also be a comprehensive oral examination at the end of the eighth semester, covering Literature and Area Studies in the candidate's languages. 


\section{Degree and Certificate}

Those regular degree students who have concluded their final examinations with the required grades, would be graduated with a B.A. in Translation, and would also receive a Certificate of Proficiency in Translation on which their language combinations would be indicated, as for example:

\section{French into English \\ Spanish into English \\ English into French}

Special Students, concluding the final examinations with the required grades, would receive the same type of Certificate as regular degree students, but, of course, no degree.

\section{Tables of Translation Courses}

The following tables show the proposed sequence of Translation courses as listed above in the Curriculum, with credit hours per week:

\begin{tabular}{|c|c|c|}
\hline \multirow{4}{*}{$\begin{array}{l}\text { Third semester } \\
\text { Fourth semester } \\
\text { Fifth semester }\end{array}$} & B LANGUAGE INTO A LANGUAGE & \multirow{2}{*}{$\begin{array}{c}\text { credit hours } \\
2\end{array}$} \\
\hline & \multirow{12}{*}{$\begin{array}{l}\text { General and historical texts } \\
\text { Political, educational, sociological texts } \\
\text { Conference texts I } \\
\text { Economic texts I } \\
\text { Conference texts II } \\
\text { Economic texts II } \\
\text { Scientific and technological texts I } \\
\text { Administrative and legal texts and documents } \\
\text { Commercial texts } \\
\text { Précis-writing and abstracting I } \\
\text { Literary texts } \\
\text { Scientific and technological texts II } \\
\text { Précis-writing and abstracting II } \\
\text { Oral interpretation of business negotiations } \\
\quad \text { from and into A and B }\end{array}$} & \\
\hline & & 2 \\
\hline & & 2 \\
\hline & & $\frac{2}{2}$ \\
\hline Sixin semester & & 2 \\
\hline Seventh semester & & 2 \\
\hline & & 2 \\
\hline & & 1 \\
\hline \multirow{4}{*}{ Eighth semester } & & 2 \\
\hline & & $\begin{array}{l}2 \\
1\end{array}$ \\
\hline & & \\
\hline & & $\frac{1 / 2}{2216}$ \\
\hline \multirow{6}{*}{$\begin{array}{l}\text { Seventh semester } \\
\text { Eighth semester }\end{array}$} & C LANGUAGE INTO A LANGUAGE & \\
\hline & General and historical texts & 2 \\
\hline & Economic texts & 2 \\
\hline & Conference texts & 2 \\
\hline & Administrative and legal texts and documents & $\frac{1}{2}$ \\
\hline & & 9 \\
\hline \multirow{5}{*}{$\begin{array}{l}\text { Fifth semester } \\
\text { Sixth semester } \\
\text { Seventh semester }\end{array}$} & A LANGUAGE INTO B LANGUAGE & \\
\hline & General and historical texts & 2 \\
\hline & Political, educational, sociological texts & 2 \\
\hline & Conference texts & $\overline{2}$ \\
\hline & Economic texts & 2 \\
\hline \multirow{8}{*}{ Eighth semester } & Commercial texts & 1 \\
\hline & $\begin{array}{l}\text { Scientific and technological texts } \\
\text { Oral interpretation of business negotiations }\end{array}$ & 2 \\
\hline & from and into $A$ and $B$ & $1 / 2$ \\
\hline & & $111 / 2$ \\
\hline & SUMMARY & \\
\hline & B language into A language & $231 / 2$ \\
\hline & $\begin{array}{l}\text { A language into A language } \\
A \text { language }\end{array}$ & $111 / 2$ \\
\hline & Total credit hours in Translation & $\overline{44}$ \\
\hline
\end{tabular}




\section{B) INTERPRETER TRAINING}

Those students who wish to obtain also the B.S. in Interpretation and the Certificate of Proficiency in Interpretation, would have to study an additional year after having passed on oral aptitude test. Only students who obtained their B.A. in Translation would be eligible for a B.A. in Interpretation. Special Students who obtained the Certificate of Proficiency in Translation would be eligible for the Certificate of Proficiency as Conference Interpreters, but not for the B.A. in Interpretation.

The following curriculum is proposed for the fifth year, the training in Interpretation:

\section{FIFTH YEAR}

NINTH SEMESTER

Consecutive Interpretation

Technique of note-taking (4-week course in

credit hours

English, meeting 6 hours a week, for all inter-

preter students, regardless of their language

combinations)

Consecutive Interpretation

From $B$ lang. into $A$ lang. (starting after

completion of the course on note-taking) I

From $\mathrm{C}$ lang. into $\mathrm{A}$ lang. (starting after

completion of the course on note-taking) I

From A lang. into B lang. (starting after

completion of the course on note-taking) I

Public Speaking and Memory training

(in English)

From $\mathrm{B}$ lang. into A lang. I

From $C$ lang. into A lang. I

From A lang. into B lang. I

Précis-writing and abstracting from $A$ into $B$

Conference Terminology (for all interpreter

students, regardless of their language

combinations)

Elements of Parliamentary Procedure

(in English)

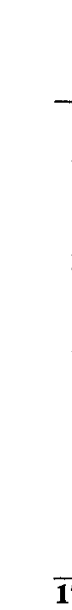

\section{TENTH SEMESTER}

Round Table discussions, with simultaneous and consecutive interpretation in various languages, and précis-writing

From $B$ lang. into $A$ lang. II

From $C$ lang. into A lang. II

From A lang. into B lang. II

From B lang. into A lang. II

From $C$ lang. into $A$ lang. II

From A lang. into B lang. II

Workshop on Comparative Terminology

(for all interpreter students, regardless

of their language combinations)

Interpretation as a Profession (in English)

1

2

2

$\frac{1}{17}$

Deontology

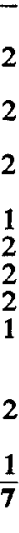

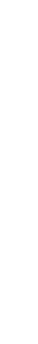

4
1
1
1
2
2
2
2
2
1
16

In the training in Consecutive and Simultaneous Interpretation, all the subject matters studied in the preceding years should be utilized in turn. The Terminology course in the tenth semester should deepen the knowledge of students in various fields and should be coordinated, as to subject matters, with the courses in Consecutive and Simultaneous Interpretation. 
No additional thesis should be required for the B.A. in Interpretation. Final examinations in Consecutive and Simultaneous Interpretation should be comprehensive and open to the public; other courses would end with the usual semestrial examinations. For the finals in Interpretation, examiners from the outside should join the Faculty; among these guest examiners should be representatives of Language Service Divisions of Government and International Agencies as well as conference interpreters of recognized standing.

C) SUMMARY OF CREDIT HOURS

FOR TRANSLATORS AND INTERPRETERS

Credit hours for all semesters are summarized in the following table:

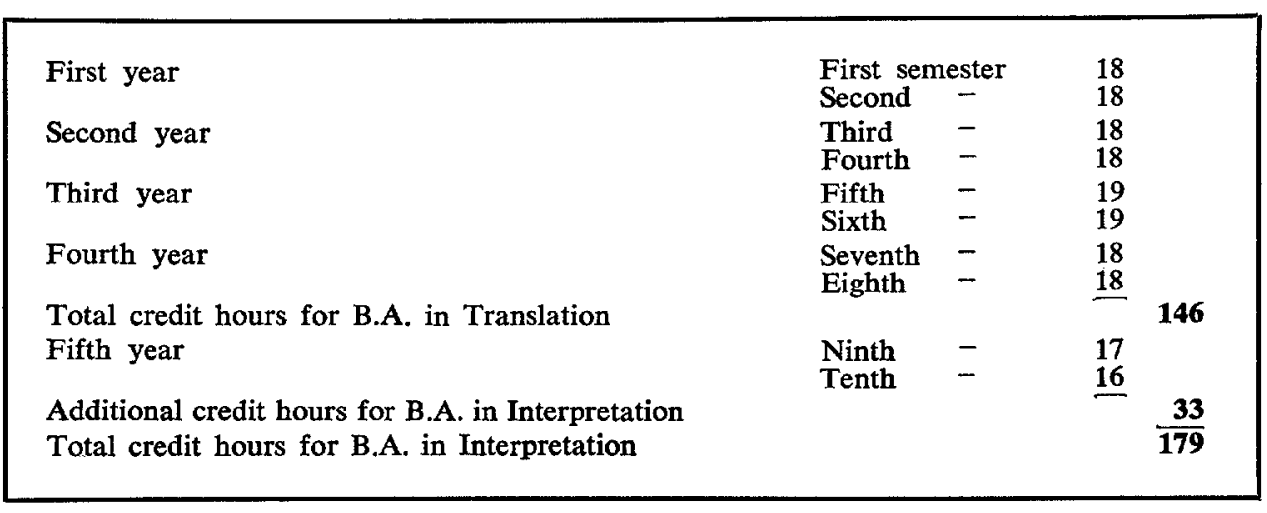

\section{CONCLUSION}

It may not be possible for an existing Language School of a College or University, to introduce the curriculum as outlined above, or a similar one, right away in its entirety. Use would have to be made of existing courses, particularly in the subject matters, and necessary changes will have to be made over a number of years.

Schools will have to restrict the number of languages they wish to include in the program. In this respect, close cooperation and consultation with professional associations of translators and interpreters should guide school authorities in their choice of languages to be included in the curriculum in order to give their graduates the best chances to find work.

STEFAN F. HORN Washington, D.C. 